\title{
Isolation and Characterization of Hydrocarbon-utilizing Bacteria from Petroleum Sludge Samples obtained from Crude Oil Processing Facility in Nigeria
}

\section{*11WOKEM, VINCENT C; ODOKUMA, LUCKY. O; ARIOLE, CAROLINE N.}

\author{
Department of Microbiology, \\ University of Port Harcourt \\ P.M.B 5323, Port Harcourt, Nigeria. \\ *E-mail: chineduvin@yahoo.com.Phone:08130306131
}

\begin{abstract}
The isolation and characterization of hydrocarbon-utilizing bacteria from petroleum oily sludge collected from crude oil processing plant in Rivers State, Nigeria was carried out. Microbiological analysis of the sludge sample showed that the microbial load consisted average of $2.5 \times 10^{6} \mathrm{cfu} / \mathrm{g}$ total heterotrophic bacterial (THB) count, while the hydrocarbon utilizing bacterial (HUB) count was average of $2.0 \times 10^{3} \mathrm{cfu} / \mathrm{g}$. Phenotypic characteristics and phylogenetic analysis of the 16S rRNA gene sequence of the isolates revealed that they were related to members of the species Klebsiella pneumonia, Klebsiella oxytoca and Alcaligenes faecalis. The 16S rRNA of the isolates showed percentage similarities to the type strains (99\% sequence similarities) of the following; Klebsiella pneumonia strain B21 (gi: 922317936), Klebsella pneumonia strain ICB-C183 (gi: 908478837), Klebsella oxytoca strain BCNAI (gi: 846993354), Klebsella oxytoca strain BC4 (gi: 884060138), Alcaligenes faecalis strain IOU PMR (gi: 686028963) and Alcaligenes faecalis strain AQ-I (gi: 816845513). Of the six hydrocarbon utilizing bacteria identified, 4(67\%) were Klebsiella species while $2(33 \%)$ were identified as Alcaligenes sp of different strains. The result suggest that these isolated organisms from the petroleum sludge can be explored and used to promote environmentally friendly technology clean-up of petroleum hydrocarbon polluted sites in the Niger Delta region of Nigeria.@ JASEM

https://dx.doi.org/10.4314/jasem.v21i2.17
\end{abstract}

Keywords: Hydrocarbon -utilizing bacteria, Petroleum sludge, 16S rRNA, Phylogenetic, Gene sequence.

One of the most encountered pollutants in the crude oil exploration and production companies is the crude oil that is entrapped with the effluents during treatment, conditioning and storage of crude oil. The oily waste (sludge) is semi- emulsified mixture of oxidized crude oil, water and miscellaneous solids (corrosion product, sand, silt and clay). These petroleum wastes and crude oil enter into the environment through the activities of petroleum extraction, refining, transportation, storage, bad practices (human error), accidents, illegal dumping of crude oil wastes, and leakages due to corrosion of tanks and pipelines as well as vandalization. The release of hydrocarbon pollutants into the environment whether accidentally or due to human error is the main cause of water and soil pollution. Fortunately, microorganisms are highly efficient and versatile in their ability to degrade hydrocarbons; (Odokuma and Dickson 2003; Head et al., 2006; Odokuma and Smith 2007; Adebusoye et al., 2007). Bacteria that biodegrade polynuclear aromatic hydrocarbons (PAHs), monoaromatic hydrocarbons and aliphatic hydrocarbons are readily isolated from the environment that have been contaminated with petroleum hydrocarbon (Chamkha et al., 2011;
Manchola and Dussan, 2014). A reviewed list of bacterial genera has listed 79 genera that can utilize hydrocarbon as the sole source of carbon and energy (Head et al., 2006). The effect of hydrocarbon contaminants on human health and the environment can not be over emphasized. It is therefore important to reduce or eliminate the total petroleum hydrocarbon (TPH) content in petroleum sludge by applying desirable property of hydrocarbon-utilizing bacteria isolated or found in the contaminated environments. This study was therefore aimed at isolating and characterizing hydrocarbon- utilizing bacteria from petroleum sludge sample collected from crude oil processing plant.

\section{MATERIALS AND METHODS}

Sample collection: The petroleum oily sludge sample used in the study was collected from crude oil processing plant located at Obegi community in Ogba-Egbama Ndoni Local Government Area of Rivers State, Niger Delta, Nigeria. Fresh sludge samples were collected directly from different sludge outlet valves in the plant and mixed together into a $500 \mathrm{ml}$ glass jar and covered. The sludge sample was transported in ice pack to the microbiology research 
laboratory of the University of the Port Harcourt for analysis. The sludge sample was preserved in the refrigerator at $4^{0} \mathrm{C}$.

Reagents: The entire reagents used in this study were of analytical grade and were obtained from $\mathrm{BDH}$ chemicals limited, Poole England. Nutrient agar (NA), and MacConkey's agar were obtained from International diagnostic group; England. Filter Paper (What man No.1) was obtained from WER Bauston Limited. The Bonny light crude oil used for hydrocarbon utilizing bacterial (HUB) test was obtained from Port Harcourt Refinery Company, Eleme, Rivers State Nigeria.

Enumeration of bacterial populations: The total heterotrophic bacterial (THB) and hydrocarbon utilizing bacterial (HUB) counts of the petroleum oil sludge were carried out by ten-fold serial dilution with normal saline. One gram of petroleum sludge was weighed into test tubes containing $10 \mathrm{ml}$ normal saline. Then $1 \mathrm{ml}$ was transferred from the stock into another test tube containing $9 \mathrm{ml}$ normal saline giving $10^{-1}$ dilution. This was repeated up to $10^{-3}$. Aliquots of dilution $(0.1 \mathrm{ml})$ were inoculated onto nutrient agar (NA) plates in triplicates using spread plate method (APHA, 1998). The plates were incubated at $37^{\circ} \mathrm{C}$ for 24h. The HUB count was carried out in triplicates on mineral salt agar (MSA) of Mills et al., 1978 as modified by Okpokwasili and Odokuma (1990). MSA was composed of $0.29 \mathrm{~g}$ of $\mathrm{KCl}, 10 \mathrm{~g}$ of $\mathrm{NaCl}$, $0.42 \mathrm{~g}$ of $\mathrm{MgSO}_{4} .7 \mathrm{H}_{2} \mathrm{O}, 0.42 \mathrm{~g}$ of $\mathrm{NH}_{4} \mathrm{NO}_{3}, 1.25 \mathrm{~g}$ of $\mathrm{K}_{2} \mathrm{HPO}_{4}, 0.83 \mathrm{~g}$ of $\mathrm{KH}_{2} \mathrm{PO}_{4}$ and $15 \mathrm{~g}$ of agar all dissolved in one litre of distilled water and autoclaved at $121^{\circ} \mathrm{C}$ for $15 \mathrm{mins}$. Aliquots of $0.1 \mathrm{ml}$ of dilution was inoculated onto MSA plates in triplicates by spread plate method (APHA, 1998). Sterile filter papers (What man No.1) saturated with Bonny light crude oil were aseptically placed on the inside lid of each plate and kept in an inverted position and incubated at $37^{\circ} \mathrm{C}$ for $48 \mathrm{~h}$. Plates were enumerated after incubation period. The filter paper saturated with crude oil served as a sole source of carbon and energy.

Isolation and identification of HUB: Culturable bacteria isolates from the HUB plates were subcultured onto NA plates and incubated at $28^{\circ} \mathrm{C}$ for 24h. Distinct colonies were further sub-cultured onto slant NA in Bijou bottles and incubated at $28^{\circ} \mathrm{C}$ for 24h. The NA slant cultures were stored in a refrigerator at $4^{\circ} \mathrm{C}$ and served as pure stock culture for subsequent characterization and identification of the isolates. Standard characterization tests were performed as described by Cheesbrough, (2006) which included Grams staining, motility, methyl-red,
Vogues- Proskauer, indole, citrate utilization and sugar fermentation. The pure isolates were identified on the basis of their cultural, morphololoical and physiological characteristics (Cheesbrough, 2006).

Molecular Identification of Isolates: DNA extraction: DNA extraction was carried out by using a ZR fungal/ bacterial DNA Miniprep extraction kit obtained from Inquaba, South Africa. The DNA extraction protocol was based on manufacturer's instruction. Heavy growth of the pure six isolates subcultured on MacConkey's agar plates were suspended in $200 \mu \mathrm{l}$ of isotonic buffer into ZR bashing bead lysing tubes, $750 \mu$ l of Lysing solution was added. They were processed at maximum speed for 5mins. The ZR Bashing bead lysing tubes were centrifuged at $10,000 \mathrm{xg}$ for $1 \mathrm{~min}$. Four hundred (400) $\mu \mathrm{l}$ of the supernatants were transferred into ZYMO-spin IV spin filter in collection tubes and centrifuged at $7000 \mathrm{xg}$ for $1 \mathrm{~min}$. The amount of $1,200 \mu \mathrm{l}$ of fungal/bacterial DNA binding buffer was added to each filtrate in the collection tubes bringing the final volume to $1,600 \mu 1,800 \mu l$ was then transferred into ZYMO-spin11C column in a collection tube and centrifuged at $10,000 \mathrm{xg}$ for $1 \mathrm{~min}$, the flow through were discarded from the collection tubes. The remaining volumes were transferred to the same ZYMO-spin and spun at 10,000xg for $1 \mathrm{~min}$. Two hundred (200) $\mu$ l of the DNA pre-wash buffer were added to the ZYMO-spin $11 \mathrm{C}$ in new collection tubes and spun at $10,000 x \mathrm{x}$ for $1 \mathrm{~min}$ followed by addition of $500 \mu \mathrm{l}$ of fungal/bacterial DNA wash buffer and centrifuged at $10,000 \mathrm{xg}$ for $1 \mathrm{~min}$. The ZYMO-spin $11 \mathrm{C}$ column were transferred to clean $1.5 \mu \mathrm{l}$ centrifuge tubes and $100 \mu \mathrm{l}$ of DNA elution buffer were added to the column matrix and centrifuged at $10,000 \mathrm{xg}$ for 30 seconds to elute the DNA. The ultra-pure DNA of each isolate properly labeled were then stored at $-20^{\circ} \mathrm{C}$ for use. After extraction, the DNA samples were quantified using NANODROP (ND1000).

PCR amplification of $16 S$ rRNA: The $16 \mathrm{~S}$ of the rRNA genes of the isolates were amplified using the $27 \mathrm{~F}$ and $1492 \mathrm{R}$ primers on a PCR System (9700 Applied Bio system thermal cycler) at a final volume of $25 \mu$ l for 40 cycles. The PCR mix include: the $\mathrm{x} 2$ Dream tag master mix supplied by Inquaba, South Africa (tag polymerase, DNTPs, $\mathrm{MgCl}_{2}$, the primers at a concentration of $0.4 \mathrm{M}$ and extracted DNA as a template. The PCR conditions were as follows: initial denaturation, $95^{\circ} \mathrm{C}$ for 4 mins; denaturation $95^{\circ} \mathrm{C}$ for $30 \mathrm{~s}$; Annealing, $52^{\circ} \mathrm{C}$ for 3 mins. Then holding temperature at $4^{0} \mathrm{C}$. The products were resolved on a $1 \%$ agarose gel at $120 \mathrm{v}$ for $15 \mathrm{~min}$ and visualized on a 
UV transilluminator ( $\mathrm{C} e^{-}$bron et al., 2008). The generated PCR products were dried and sent to Inquaba (South Africa) for purification and sequencing using an AB13500 genetic analyzer adopting the Bigdye Termination technique by Inquaba South Africa.

Phylogenetic analysis: The sequences were edited using the bio informatics algorithm Bioedit. Similar sequences were downloaded from the National Biotechnology Information Centre (NCBI) data base using Blast $\mathrm{N}$, these sequences were aligned using cluster IX. The evolutionary history of the isolates was inferred using Neighbor - Joing method in MEGA 6.0 (Thompson et al., 1994). The bootstrap consensus tree inferred from 500 replicates was taken to represent the evolutionary of the taxa analyzed (Felsenstein, 1985)

\section{RESULTS AND DISCUSSION}

Table 1: Bacterial and Fungal Population of Petroleum Oily Sludge Sample

\begin{tabular}{ll}
\hline Type of count & Value \\
\hline THB & $2.5 \times 10^{6} \mathrm{cfu} / \mathrm{g}$ \\
HUB & $2.0 \times 10^{3} \mathrm{cfu} / \mathrm{g}$ \\
\hline
\end{tabular}

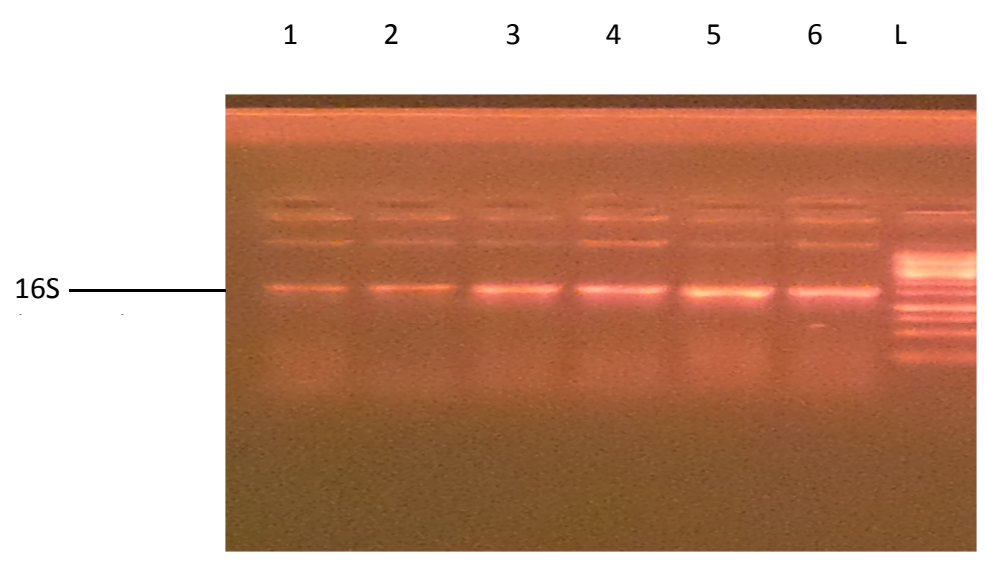

Fig. 1: Agarose electrophoresis of the 16S gene bands of the isolates:

$\mathrm{L}$ : represents the $1 \mathrm{~kb}$ ladder, 1-6 represents $16 \mathrm{~S}$ gene bands of the isolates.

\begin{tabular}{|c|c|c|}
\hline \multicolumn{3}{|c|}{$\begin{array}{l}\text { IDENTIFICATION OF ISOLATES WITH ACCESSION NUMBERS } \\
\text { HUB isolates identified using } 16 \mathrm{~S} \text { rRNA gene nucleotide sequence(s) }\end{array}$} \\
\hline Klebsiella pneumonia strain B21 & - & SUB1917764B1 KX817218 \\
\hline Klebsiella pneumonia strain ICB-C183 & - & SUB1917764B2 KX817219 \\
\hline Klebsiella oxytoca strain BCNA1 & - & SUB1917764B3 KX817220 \\
\hline Klebsiella oxytoca strain BC4 & - & SUB1917764B4 KX817221 \\
\hline Alcaligenes faecalis strain IOU PMR & - & SUB1917764B5 KX817222 \\
\hline Alcaligenes faecalis strain AQ-1 & - & SUB1917764B6 KX817223 \\
\hline
\end{tabular}

The bacterial populations of the sludge sample are presented in Table 1 . The enumeration of high population of THB $\left(2.5 \times 10^{6} \mathrm{cfu} / \mathrm{g}\right)$ and HUB counts of $2.0 \times 10^{3} \mathrm{cfu} / \mathrm{g}$ respectively is an indication that the sludge sample could be degraded by the indigenous hydrocarbon- utilizing bacteria isolated from the oily sludge sample (Ojo, 2006; Manchola and Dussan, 2014). The enumeration of these bacterial populations from the oily petroleum sludge implies that the bacterial genera are able to utilize crude petroleum oil hydrocarbons as the sole source of carbon and energy. Manchola and Dussan (2014) in a study to evaluate the ability of seven strains belonging to Lysinibacillus sphericus and Geobacillus species isolated from an off-shore "sercina" oil field, to biodegrade TPH in the presence 
of toxic metals, their potential to produce biosurfactants, and their ability to improve the biodegradation rate, reported that the bacterial strains were able to utilize crude petroleum oil hydrocarbons as the sole source of carbon and energy. In addition, their ability to degrade crude oil was not affected by the presence of toxic metals such as chromium and arsenic. At the same time, the strains were able to reduce toxic metals concentration through biosorption processes. (Manchola and Dussan, 2014).

The cultural and colonial characteristics showed that the colonies were of various shapes and forms such as large, raised, moist and mucoid, while others were non-slime (non mucoid) on NA plates.

Morphological characterization of the isolates all showed Gram-negative, non-sporing, non-motile short rods. Biochemical reactions showed catalase positive, oxidase negative, indole negative, VogusProskauer positive, citrate positive and various reactions to other biochemical reactions. The results suggested Klebsiella and Alcaligenes species.

The phylogenetic analysis of the 16S rRNA gene sequence results of the isolates produced an exact match during mega blast search for highly similar sequences from the NCBI non-redundant nucleotide (nr/nt) database. The $16 \mathrm{~S}$ rRNA of the isolates showed percentage similarities to other species at $99 \%$ being most closely related to Klebsiella pneumonia, Klebsiella oxytoca and Alcaligenes faecalis. The evolutionary distances computed using Jukes-cantor methods were in agreement with the phylogenetic placement of the $16 \mathrm{~S}$ rRNA of the isolates within the type strains of the following: Klebsiella pneumonia strain B21 (gi: 922317936), Klebsiella pneumonia strain ICB-C183 (gi: 908478837), Alcaligenes faecalis strain IOU PMR (gi: 686028963), Alcaligenes faecalis strain AQ-1 (gi: 816845513), Kebsiella oxytoca strain BCNAI (gi: 846993354) and Kebsiella oxytoca strain BC4 (gi: 884060138) respectively.

Previous studies have reported the involvement of many genera of bacteria in hydrocarbon degradation and use them as a source of carbon and energy (Head, 2006; Bhattacharya, 2003), but there are few reports that suggest that enteric bacteria especially those of genera Klebsiella, Enterobacter, Escherichia coli and Hafnia have the ability to degrade hydrocarbons (Diaz, et al., 2001; Serma et al., 2004). Klebsiella pneumonia is ubiquitous as it is found in mammals and ecological environment. It is an important cause of human infections. Infections or diseases are usually nosocomial or hospital-acquired (Podschum and Ullmann, 1998). The results of isolation and identification of Klebsiella Pneumonia and $K$. oxytoca to the strain levels in this study, agree with previous studies that implicated the same organisms in petroleum hydrocarbon degradation. Chamkha et al., (2011) reported the isolation and characterization of Klebsiella oxytoca strain degrading crude oil from Tunisian off-shore oil fields, similarly, Rodrigues et al., (2009) had earlier reported diversity of hydrocarbon-degrading Klebsiella strains isolated from hydrocarbon-contaminated estuaries. The oildegrading Klebsiella isolates obtained from the estuary were closely related to Klebsiella pneumonia and Klebsiella ornithinnolytica. The isolates demonstrated a substantial degree of catabolic plasticity for hydrocarbon degradation. ( Diaz, 2001; Sarma et al., 2004). Alcaligenes faecalis isolated from the oily sludge sample, in this study, is an aerobic gram-negative rod-shaped motile organism that occur or inhabit soil and water (Austin et al., 1981). Bharali et al., (2001) explored the use of Alcaligenes faecalis to promote biodegradation of petroleum hydrocarbons. A. faecalis produces biosurfactant compounds that increase the hydrophobicity of the cell surface during growth on hydrocarbons that enhances the contact with the hydrocarbons and as a result increases hydrocarbon degradation. In the study by Bharali et al., (2001), the capacity to produce biosurfactant was demonstrated by growing $A$. faecalis in salt media with a variety of hydrophobic substances (diesel, kerosene, crude oil) as the carbon source. Under different substrate concentrations surface tension and the rate of biosurfactant production were measured. It was found that biosurfactant produced by A.faecalis possessed high surface activity, decreasing surface tension adequately to allow for degradation by the microorganisms (Bharali et al., 2001).

In conclusion, from the findings of this study, it suggest that the organisms isolated and identified as Klebsiella pneumonia, K. oxytoca and Alacaligenes faecalis of different strains have the potential to degrade hydrocarbon pollutants when applied in the environmentally friendly technology clean-up ( bioremediation ) of hydrocarbon contaminated sites in the Niger Delta of Nigeria.

\section{REFERENCES}

Adebusoye, S.A; Illori M.O; Amund, O.O; Teniola, O.D; Olatope, S.O (2007). Microbial degradation of petroleum hydrocarbons in a polluted tropical stream. World J. Microbiol. Biotechnol. 23: 1149-1159. 
American Public Health Association-APHA (1998) Standard methods for the examination of water and wastewater. $20^{\text {th }}$ ed. Washington, D.C. American wastewater Association, water pollution control.

Austin, B; Cowell, R.R; Forns, J.M; Rodgers; C.J (1981). Alcaligenes faecalis subsp. homari subsp. nov., a new group of bacteria isolated from moribund lobstars. Int. J. Systematic Bacteriol. 31(1):72-76.

Bharali, P; Das, S; Konwar, B.K; Thakur, A.J (2001). Crude biosurfactant from thermophilic Alcaligenes faecalis: Feasibility in petro-spill bioremediation. Int. Biodeterioration and Biodegradation 65: 682-690.

Bhattacharya, D; Sarma, P.M; Krishman, S; Mishra .S; Lal. B (2003). Evaluation of genetic diversity among Pseudomanas citroneltolic strains isolated from oily sludge contaminated sites. Appl. Environ. Microbiol. 69:1435-1441.

$\mathrm{Ce}^{-}$bron, A; Norini, M. P; Beguiristain, T; Leyval, E (2008). Real- time PCR quantification of PAHring hydroxylating deoxygenase $\left(\mathrm{PAH}-\mathrm{RHD}_{\mathrm{x}}\right)$ genes from gram positive and gram negative bacteria in soil and sediment samples. $J$. Mcrobiol. Methods. 73:148-159.

Chamkha, M; Yosra, T; Sm, M; Sam, S (2011). Isolation and characterization of Klebsiella oxytoca strain degrading crude oil from Tunisian offshore oil fields. J. Basic Microbiol. 5(6): 580589.

Cheesbrough, M (2006) Distric Laboratory Practice in Tropical Countries, part 2, London, Cambridge University Press. P 58-100.

Diaz, E, Ferrandez, A, Prieto, M.A and Garcia, J.L (2001). Biodegration of aromatic compounds by Escherichia coli. Microbiol. Mol. Bio. Rev. 65:523-569

Felsenstein J. (1985) Confidence limits on phylogenies: An approach using the bootsrap method. Evolution 39:783-791.

Head, I.M; Jones, D.M; Roling, W. F (2006). Marine microorganisms make meal of oil. Nature Review of Microbiolo. 4:173-182.
Manchola, L; Dussan, J (2014). Lysinibacillus sphaericus and Geobacillus sp.Biodegradation of petroleum hydrocarbons and biosurfactant production. Remed. J. 25(1): 85-100.

Mills, A.L; Breuil, C Cowell, R.R (1978). Enumeration of petroleum- degrading marine and estuarine micro organisms by the most probable number (MPN) Method. Canadian $J$. microbiol. 24:552-557.

Odokuma, L.O; Dickson, A.A (2003). Bioremediation of a crude oil polluted tropical mangrove environment J. Appl. Sci. Environ. Manage. 7 (2); 23-29.

Odokuma, L.O; Smith, V.A (2007). Bioremediation of a Nigerian crude oil by Chroccoccus and Chlorella species. Tropical Freshwater Biology. 16(1):17-30.

Ojo, O.A (2006) Petroleum-hydrocarbon utilization by native bacterial population from a waste water canal. African J.Biotechnol. 2:288-292.

Okpokwasili, G.C; Odokuma, L.O (1990). Effect of salinity on biodegradation of oil spill dispersants. Waste Manage. 10:141-146.

Podschun, R. and Ullmann, U (1998). "Klebsiella" sp. as Nosocomial Pathogens: Epidemiology, Taxonomy, Typing methods, and pathogenicity factor. Clinical Microbiol. Reviews 11(4):589603.

Rodrigues, D.F; Sakaka, S.K; Comasseto, J.V; Bic, M.C; Pellizari, V.H (2009) Diversity of hydro carbon- degrading Klebsiella Strains isolated from hydrocarbon- contaminated estuaries. J.Appl.Microbiol.106 (2): 1304-13014.

Sarma, P.M; Bhttacharya, D; Krishan, S; Lal, B (2004). Degradation of polycyclic aromatic hydrocarbons by a newly discovered enteric bacterium, Leclercia adecarboxylata. Appl.Environ. Microbiol. 70: 3163-3165.

Thompson, J.D; Gibson, T.J; Plewniak, F; Jenmougin, F; Higgins, D.G (1994). The cluster $1 \mathrm{X}$ windows interface: Flexible strategies for multiple sequence alignment aided by quality analysis tools. Nucleic Acids Res. 22:4673-4680. 